DOI: 10.18522/1997-2377-2020-110-1-103-107

УДК: 338.226

\title{
THE BALANCED INDICES SIGNIFICANCE IN THE ACTIVITY ASSESSMENT OF RAILWAY STRUCTURAL DIVISIONS (IN TERMS OF CARGO TRANSPORTATION)
}

N.M. Magomedova, M.V. Khlebnikova

Определены основные показатели оценки структурных подразделений железнодорожного транспорта. Представлены характерные особенности показателей деятельности предприятий железнодорожного транспорта. Определены основные задачи оценки планирования структурных подразделений. Учтены основные условия: своевременное принятие решений современных рыночных отношений. На основе реализации поставленных задач предложены способы совершенствования перевозочного процесса на местном уровне в рамках отдельных структурных подразделений. Предложенная модель позволит повысить эффективность деятельности структурных подразделений ОАО «РЖД», что в свою очередь может оказать положительное влияние на экономику транспорта в области рыночных отношений.

Ключевые слова: железнодорожный транспорт, структурное подразделение, процесс транспортировки грузов, математический метод, рыночные отношения, оценка, внутренний отраслевой рынок

Литература

1. Belozerov O.V. Railways must not be the brake for economic development // https:// ria.ru/20180522/1521019975

2. Novosel'skaya S.A. Effectiveness of the structural subdivision of OAO Russian Railways: on the construction of the system indeces // Problems of modern economy. 2011. No. 3 (39).

3. Chestnov P.E. Railway infrastructure development as a method of strenghening the national economy // Transport business in Russia. 2013. No. 2.

4. Tereshina B.M. The economy of railway transport. M., 2008.

5. https://www.eng.rzd.ru/statice/public/en?STRUCTURE_ID=4. - Russian Railways.

6. http://.vestifinance.ru/articles/124306. - Vesti Economics.

7. Taylor F.W. The Principles of Scientific Management. Dover Pubns. 1998.

8. Gulick L.H., Urwick L.F. Papers on the science of administration. New York: Garland Pub, 1987.

9. The strategy of "RZD" development for the period until 2030 (the main principles) // https: doc. rzd.ru/public//ru/?STRUCTURE_ID=704\&layer_id=510. - Russian Railways.

10. Lapidus B.M., Macheret D. Macroeconomic Aspect of the Evolution of Railway transport. Voprosi ekonomiki. 2011 3)124-137. (in Rus) // https://doi.org.10.32609/0042-8736-2011-3-124-137.

11. http://cargo. rzd.ru

Ростовский государственный университет путей сообщения, 2. Ростов-на-Дону

24 января 2020 г. 